\title{
Erratum: Ventriculo-atrial defect after bioprosthetic aortic valve replacement
}

\author{
Jayant S. Jainandunsing ${ }^{1}$, Remco Bergman ${ }^{1}$, Jacob Wilkens², Angela Wang ${ }^{3}$, Guido Michielon² \\ and Ehsan Natour ${ }^{2^{*}}$
}

After publication of the article [1] it was discovered that this manuscript was mistakenly given a duplicated citation number. The correct citation of 9:199 has now been updated in all versions of this manuscript. We apologise for any inconvenience caused by this error.

\begin{abstract}
Author details
'Department of Anesthesia and Pain Medicine, University of Groningen, University Medical Center, Groningen, The Netherlands. ${ }^{2}$ Department of Cardiothoracic Surgery, University of Groningen, University Medical Center Groningen, Hanzeplein 1, 9700 RB Groningen, The Netherlands. ${ }^{3}$ Department of Anesthesia Critical Care and Pain Medicine, Beth Israel Deaconess Medical Center, Harvard Medical School, 330 Brookline Avenue, Boston, Massachussetts 02215, USA.
\end{abstract}

Received: 30 April 2015 Accepted: 6 May 2015

Published online: 29 May 2015

\section{Reference}

1. Jainandunsing JS, Bergman R, Wilkens J. Ventriculo-atrial defect after bioprosthetic aortic valve replacement. J Cardiothorac S. 2014;9:137.

\footnotetext{
* Correspondence: e.natour@umca.nl

${ }^{2}$ Department of Cardiothoracic Surgery, University of Groningen, University Medical Center Groningen, Hanzeplein 1, 9700 RB Groningen, The Netherlands
}

\section{Submit your next manuscript to BioMed Central and take full advantage of:}

- Convenient online submission

- Thorough peer review

- No space constraints or color figure charges

- Immediate publication on acceptance

- Inclusion in PubMed, CAS, Scopus and Google Scholar

- Research which is freely available for redistribution

Submit your manuscript at www.biomedcentral.com/submit
() Biomed Central 